\title{
THE FIRST REPORTED OCCURRENCE OF CREASEYITE, A HYDROUS LEAD-COPPER-IRON SILICATE MINERAL, IN SOUTH-AMERICA
}

\author{
KITARO HAYASE and JORGE A. DRISTAS*
}

\begin{abstract}
An acicular deep-green mineral was discovered in an oxidation zone of the Cruz del Sur lead-copper deposit, Rio Negro province, Argentina. This mineral was studied by petrographic microscopy, X-ray powder diffraction methods, chemical analysis, infrared spectroscopy and electron microscopy and identified as the "creaseyite" reported by Williams and Bideaux (1975). The chemical analyses of the mineral here presented are somewhat different from those of the Arizona and Sonora creaseyite. This is the first reported occurrence of creaseyite in South-America.
\end{abstract}

RESUMO Um mineral acicular de coloração verde-escura foi encontrado na zona de oxidação do depósito de chumbo e cobre de Cruz del Sur, Rio Negro, Argentina. Esse mineral foi objeto de estudos por microscopia petrográfica, difração de raios X, análise química, espectroscopia de infra-vermelho e por microscopia eletrônica, tendo sido identificado como "creaseyita", de acordo com Williams e Bideaux (1975). As análises químicas apresentadas diferem um pouco daquelas obtidas para a creaseyita do Arizona e de Sonora. Essa é a primeira ocorrência descrita de creaseyita na América do Sul.

INTRODUCTION Creaseyite, first found by R. A. Bideaux in 1967, and by S.A. Williams in 1968 , is a new mineral of formula $\mathrm{Cu}_{2} \mathrm{~Pb}_{2}\left(\mathrm{Fe}, \mathrm{Al}_{2} \mathrm{Si}_{5} \mathrm{O}_{17} 6 \mathrm{H}_{2} \mathrm{O}\right.$, orthorhombic diffraction symbol $m m m C b$ (Williams and Bideaux, 1975).

A brittle, finely acicular, deep-green mineral was found in 1973 by the present authors in an oxidation zone of a lead-copper deposit of Cruz del Sur mine, Rio Negro Province, Southwestern Argentina. Its X-ray powder pattern did not correspond to that of any known species, and the mineral could not be identified at that time. Its definitive chemical composition was determined only three years later; in the meantime, the mineral was considered to be a hydrous lead-copper-iron silicate, on account of preliminary spectroscopic and microchemical tests.

Further study by the writers, by means of X-ray diffraction, wet chemical analysis, infrared spectroscopy and petrographic and electron microscopy, showed this mineral to be creaseyite, though with a chemical composition somewhat different from that reported by Williams and Bideaux (1975). This is the first occurrence of creaseyite in South America.

OCCURRENCE The lead-copper deposit of the Cruz del Sur mine is situated at about $38 \mathrm{~km}$ east-south-eastward of Los Menucos village, Rio Negro province, Argentina (Fig. 1). A shallow inclined shaft, about $15 \mathrm{~m}$ deep, exposes only the outer oxidation zone with a complex mineralogy, presenting galena, chalcocite, digenite, covellite, malachite, azurite, cerussite, wulfenite, vanadinite, atacamite, paratacamite, mottramite (Hayase and Dristas, 1972), calcite, gypsum, limonite, and quartz. In addition, the writers have found in this oxidation zone a new mi-

* Departamento de Ciencias Naturales, Universidad Nacional del Sur, Bahia Blanca, Argentina. 
neral, "surite", a $\mathrm{PbCO}_{3}$-montmorillonite mixed layer mineral. The report on this new mineral has been submitted to I.M.A.

The mineral of this study has a fine acicular shape showing a deep green color, sometimes occurring as radial or bundle-like aggregates, associated to gypsum, quartz, cerussite and iron oxide minerals. Its crystals often reach up to $1 \mathrm{~mm}$ in length and $0.2 \mathrm{~mm}$ in width, but are usually much smaller.

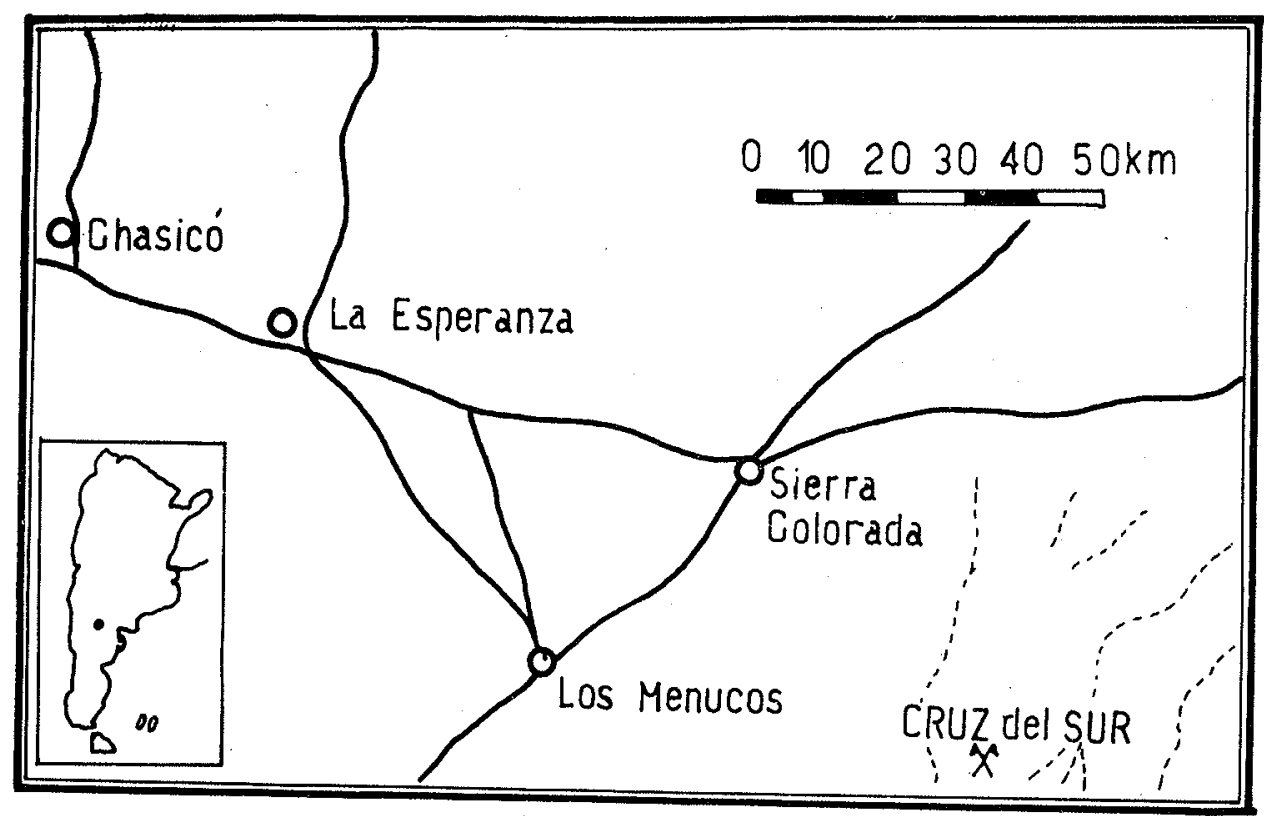

Figure 1 - Locality of Cruz del Sur mine

OPTICAL PROPERTIES Under a petrographic microscope, the creaseyite crystals have fine prismatic or tabular shapes with a distinct cleavage parallel to the elongation; sometimes creaseyite appears as bundle-like aggregates of fine needles. Frequently, termination of the needles is by planes perpendicular to their elongation, probably representing cleavages. The crystals show straight extinction with positive optic elongation and the following pleochroism: parallel to the elongation $=Z^{\prime}$, green; perpendicular to the elongation $=X^{\prime}$, pale yellowish green. The indices of refraction are: $N_{v}=1.696 \pm 0.002, N_{\beta}=1.746 \pm 0.002, N_{\gamma}=$ $=1.788 \pm 0.002, N_{y}-N_{a}=0.092$, with a calculated $2 \mathrm{~V}$, of $82^{\circ}$.

Fresh needles of this mineral appear sometimes as inclusions in rather large quartz crystals (Fig. 2) without being associated to other secondary oxidation minerals, such as iron oxide minerals, cerussite, etc. This observation suggests the possibility that this mineral is a product of hydrothermal activity or of the earliest step of oxidation. 

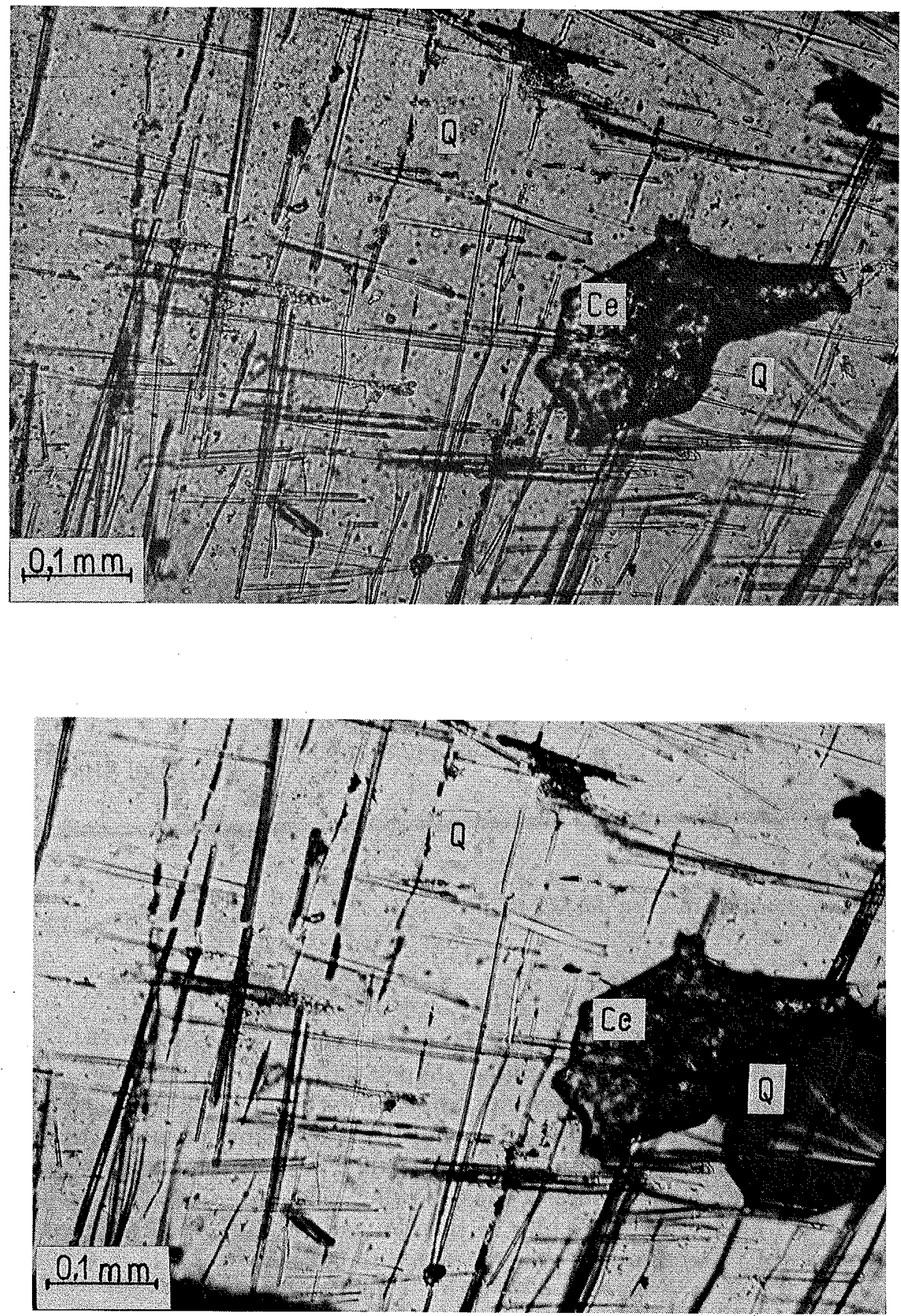

Figura 2 - Microphotograph of creaseyite. a) Lower Nicol only. b) Crossed Nicols. Acicular crystals are creaseyite, Q quartz, Ce, Cerussite 
X-RAY POWDER DIFFRACTION DATA The X-ray powder diffraction data of this mineral are shown in Tab. I. Almost all of the diffraction peaks coincide with those of the creaseyite reported by Williams and Bideaux (1975). The

Table I - X-ray powder diffraction data of creaseyite

\begin{tabular}{|c|c|c|c|c|c|c|}
\hline \multicolumn{4}{|c|}{ Mineral from Cruz del Sur mine } & \multicolumn{3}{|c|}{$\begin{array}{c}\text { Creaseyite from Tiger, } \\
\text { Arizona (1) }\end{array}$} \\
\hline$h k \ell$ & $d_{\text {meas. }}(\AA)$ & $d_{\text {calc. }(\AA)}$ & $I / I_{0}$ & hkl & $d(\AA)$ & $I / I_{0}$ \\
\hline 110,020 & 10.68 & 10.782 & 100 & 110 & 10.726 & 10 \\
\hline 130 & 6.21 & 6.202 & 17 & 130 & 6.200 & 3 \\
\hline 111 & 6.03 & 6.029 & 18 & 111 & 6.024 & 5 \\
\hline 040,220 & 5.356 & 5.362 & 29 & 040 & 5.352 & 4 \\
\hline 131 & 4.729 & 4.719 & 6 & 131 & 4.720 & 3 \\
\hline- & - & - & - & 221 & 4.327 & 2 \\
\hline 240 & 4.066 & 4.065 & 24 & 240 & 4.067 & 5 \\
\hline & & & - & 002 & 3.642 & 2 \\
\hline 330 & 3.584 & 3.594 & 23 & 330 & 3.592 & $1 / 2$ \\
\hline 060 & 3.562 & 3.574 & 23 & 060 & 3.555 & $5 \mathrm{~B}$ \\
\hline 112 & 3.444 & 3.445 & 10 & 112 & 3.448 & 3 \\
\hline 061 & 3.210 & 3.208 & 18 & 061 & 3.216 & $4 \mathrm{~B}$ \\
\hline 042,222 & 3,010 & 3.009 & 41 & 042 & 3.013 & 5 \\
\hline 350 & 2.985 & 2.985 & 40 & 350 & 2.982 & 5 \\
\hline 351 & 2.758 & 2.761 & 11 & 351 & 2.761 & 2 \\
\hline 440 & 2.692 & 2.695 & 46 & 440 & 2.696 & 5 \\
\hline 080 & 2.680 & 2.681 & 53 & 080 & 2.674 & 4 \\
\hline 332 & 2.556 & 2.556 & 5 & 332 & 2.557 & 2 \\
\hline 081 & 2.517 & 2.515 & 8 & & & \\
\hline 370 & 2.466 & 2.466 & 24 & & & \\
\hline 402 & 2.367 & 2.367 & 13 & & & \\
\hline 371 & 2.338 & 2.336 & 18 & & & \\
\hline 352 & 2.307 & 2.307 & 7 & & & \\
\hline 461 & 2931 & 2.235 & 14 & & & \\
\hline 191 & & 2.228 & & & & \\
\hline 082 & 2.159 & 2.158 & 7 & & & \\
\hline 600 & 2.081 & 2.079 & 7 & & & \\
\hline 0101 & 2.057 & 2.057 & 11 & & & \\
\hline
\end{tabular}

(1) Williams and Bideaux (1975), cell constants:

$a=12.483 \pm 0.006 \AA$,

$b=21.395 \pm 0.011 \AA$,

$c=7.283 \pm 0.004 \AA$

(B, broad)

$d_{\text {meas. }}$, measured value; $d_{\text {calc }}$, calculated value with the following cell constants: $a=12.4721 \AA$, $b=21.4465 \AA, c=7.2717 \AA, \alpha=\beta=\gamma=90^{\circ}$.

$\mathrm{X}$-ray diffraction conditions: Diffractometer-Rigaku Denki Co.; anticathode-Cu; Ni-filter; $35 \mathrm{kV} ; 12 \mathrm{~mA}$; scanning- $1^{\circ} / \mathrm{min}$; chart speed $-20 \mathrm{~mm} / \mathrm{min}$; slits $1^{\circ}, 1^{\circ}, 0.2 \mathrm{~mm}$; time const. $4 \mathrm{sec}$; rate-meter- $\mathrm{X} 8$; multiplier $\mathrm{X} 0.8$; halite $(\mathrm{NaCl})$ was used as internal standard 
cell constants of this mineral were calculated with a least square computer program using reflections $130,111,040,131,240,112,061,350,080$ and 332 with the following results: $a=12.4721 \AA, b=21.4465 \AA, c=7.2717 \AA, \alpha=\beta=\gamma=90^{\circ}$, $(\sigma=0.00343 \AA)^{*}$

The indices attributed to the reflections of the powder pattern indicate the presence of a $C$-centered lattice and a probable diffraction symbol $m m m C b$ (Stout and Jensen, 1968), as indicated by Williams and Bideaux (1975).

$\mathrm{X}$-ray peaks in the diffractogram are generally fairly sharp, thus indicating that the mineral is well-crystallized and probably formed hydrothermally before the onset of the oxidation process.

CHEMICAL COMPOSITION A sufficient amount of this mineral for analytical purposes was obtained by a repeated manual separation technique. The sample was then decomposed with gently heated aqua-regia. The insoluble residue was filtered and $\mathrm{SiO}_{2}$ in the residue was analyzed by the evaporation tecnhique with

Table II - Chemical analysis of creaseyite

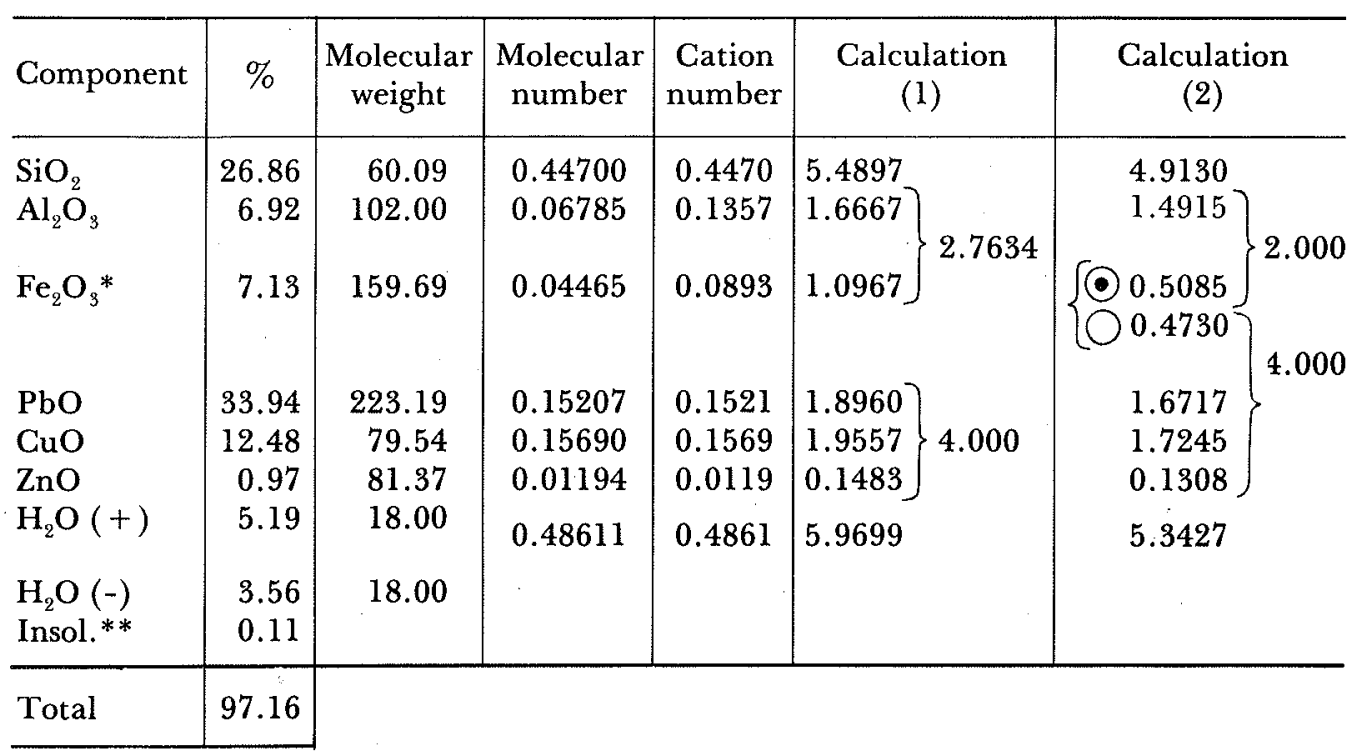

* All $\mathrm{Fe}$ analyzed as $\mathrm{Fe}^{3+}$; amount of sample was not sufficient to allow for $\mathrm{Fe}^{2+}$ analysis

** Insoluble and inert in $\mathrm{HF}$ and aqua-regia

(1) Cation number of $(\mathrm{Pb}+\mathrm{Cu}+\mathrm{Zn})$ fixed at $4.00-$ composition as follows: $\left(\mathrm{Pb}_{1.896} \mathrm{Cu}_{1.956} \mathrm{Zn}_{0.148}\right)_{4.00}\left(\mathrm{Al}_{1.667} \mathrm{Fe}_{1.097}^{\overline{8}+}\right)_{2.764} \mathrm{Si}_{5.490} \mathrm{O}_{19} 5.970\left(\mathrm{H}_{2} \mathrm{O}\right)$

(2) Cation numbers of $\left(\mathrm{Fe}^{+2}+\mathrm{Pb}+\mathrm{Cu}+\mathrm{Zn}\right)$ and $\left(\mathrm{Al}+\mathrm{Fe}^{+3}\right)$ fixed at 4.00 and 2.00, respectively - composition as follows:

$\left(\mathrm{Pb}_{1.672} \mathrm{Cu}_{1.724} \mathrm{Fe}_{0.473}^{+2} \mathrm{Zn}_{0.131}\right)_{4.00}\left(\mathrm{Al}_{1.491} \mathrm{Fe}_{0.509}^{+3}\right)_{2.00} \mathrm{Si}_{4.913} \mathrm{O}_{17} 5.343\left(\mathrm{H}_{2} \mathrm{O}\right)$

- Calculated ferric iron

Calculated ferrous iron

* Standard deviation $\sigma=\sqrt{\frac{\sum\left(d_{\text {meas. }}-d_{\text {calc }}\right)^{2}}{n-1}}$ 
HF. Lead in the filtrate was determined by a lead sulphate precipitate and checked with the results of analysis by atomic absorption spectroscopy. After the filtration of $\mathrm{PbSO}_{4}$, the total amount of $\left(\mathrm{Al}_{2} \mathrm{O}_{3}+\mathrm{Fe}_{2} \mathrm{O}_{3}\right)$ was determined by gravimetry. The titration with a standard permanganate solution was carried out to determine $\mathrm{Fe}_{2} \mathrm{O}_{3}$. The quantity of $\mathrm{Al}_{2} \mathrm{O}_{3}$ was calculated by subtraction of $\mathrm{Fe}_{2} \mathrm{O}_{3}$ from the total amount of $\left(\mathrm{Al}_{2} \mathrm{O}_{3}+\mathrm{Fe}_{2} \mathrm{O}_{3}\right)$. Copper was analyzed by the $\mathrm{KI}$ method, and $\mathrm{Zn}$ by atomic absorption spectroscopy. The positive water (released over $110^{\circ} \mathrm{C}$ ) was determined by the Penfield technique. Results are shown in Tab. II.

The most important differences between the results of this analysis and the one reported by Williams and Bideaux (1975) are that the Cruz del Sur mineral has larger $\mathrm{Al}_{2} \mathrm{O}_{3}$ and lower $\mathrm{Fe}_{2} \mathrm{O}_{3}$ contents. Tab. 2 shows two possible formulas for the Cruz del Sur mineral; the first calculation was performed taking $(\mathrm{Pb}+$ $+\mathrm{Cu}+\mathrm{Zb})$ atoms equal to 4 , the second taking $\left(\mathrm{Al}+\mathrm{Fe}^{+3}\right)=2$ and $\left(\mathrm{Fe}^{+2}+\right.$ $\mathrm{Pb}+\mathrm{Cu}+\mathrm{Zn})=4$. The formula found by Williams and Bideaux (1975):

$\mathrm{Cu}_{2} \mathrm{~Pb}_{2}(\mathrm{Fe}, \mathrm{Al})_{3} \mathrm{Si}_{5} \mathrm{O}_{17} \cdot 6 \mathrm{H}_{2} \mathrm{O}$

can not be applied to the Cruz del Sur specimen. On the other hand, the second calcuiation suggests the following as the valid formula for the Argentine creaseyite:

$\left(\mathrm{Pb}, \mathrm{Cu}, \mathrm{Fe}^{12}, \mathrm{Zn}\right)_{4}\left(\mathrm{Al}, \mathrm{Fe}^{+3}\right)_{2} \mathrm{Si}_{5} \mathrm{O}_{17} \cdot 6 \mathrm{H}_{2} \mathrm{O}$

although the analysis shows a $1.08 \% \mathrm{H}_{2} \mathrm{O}$ deficiency, probably due to analytical errors by the Penfield method.

INFRARED SPECTROSCOPY AND ELECTRON MICROSCOPY Fig. 3 shows the result of the infrared spectroscopy of this mineral. Two distinct absorption peaks are recognized near $1000 \mathrm{~cm}^{-1}$, one at about $900 \mathrm{~cm}^{-1}$ and the other at about $960 \mathrm{~cm}^{-1}$. The former may represent the stretching of Si-O-M and the latter that of $\mathrm{H}-\mathrm{O}-\mathrm{M} .(\mathrm{M}=\mathrm{Pb}, \mathrm{Cu}, \mathrm{Zn}$ and $\mathrm{Fe})$ Fig. 4 shows the electron microphotography of this mineral revealing that its crystal habit is tabular.

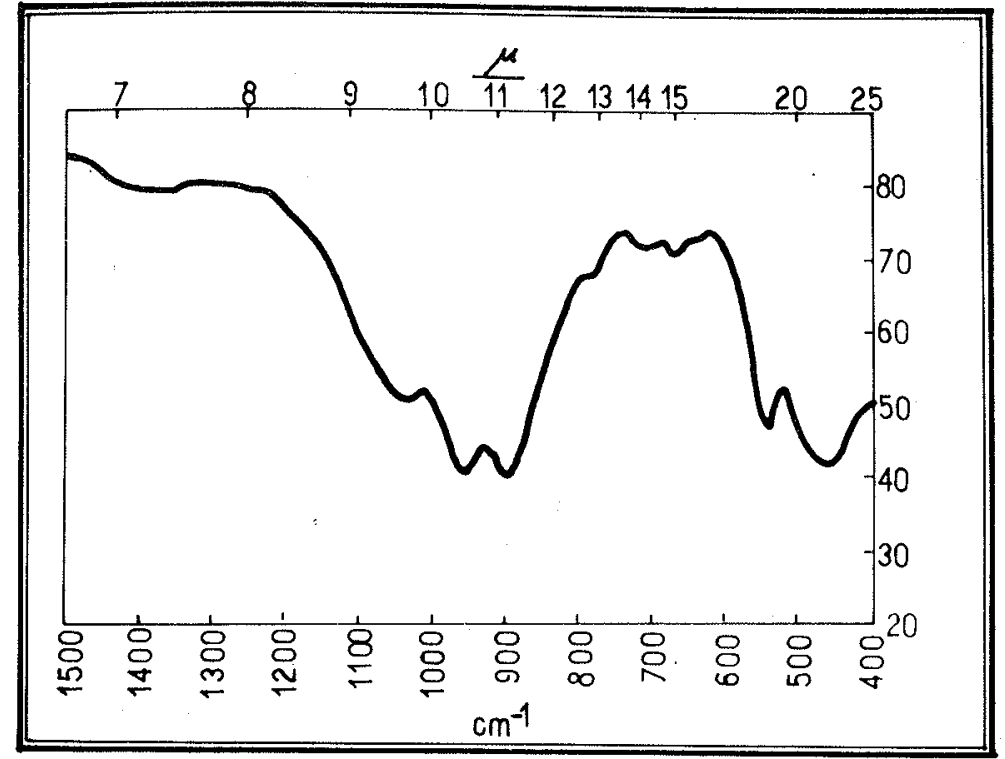

Figure 3 - Infrared spectroscopic pattern 


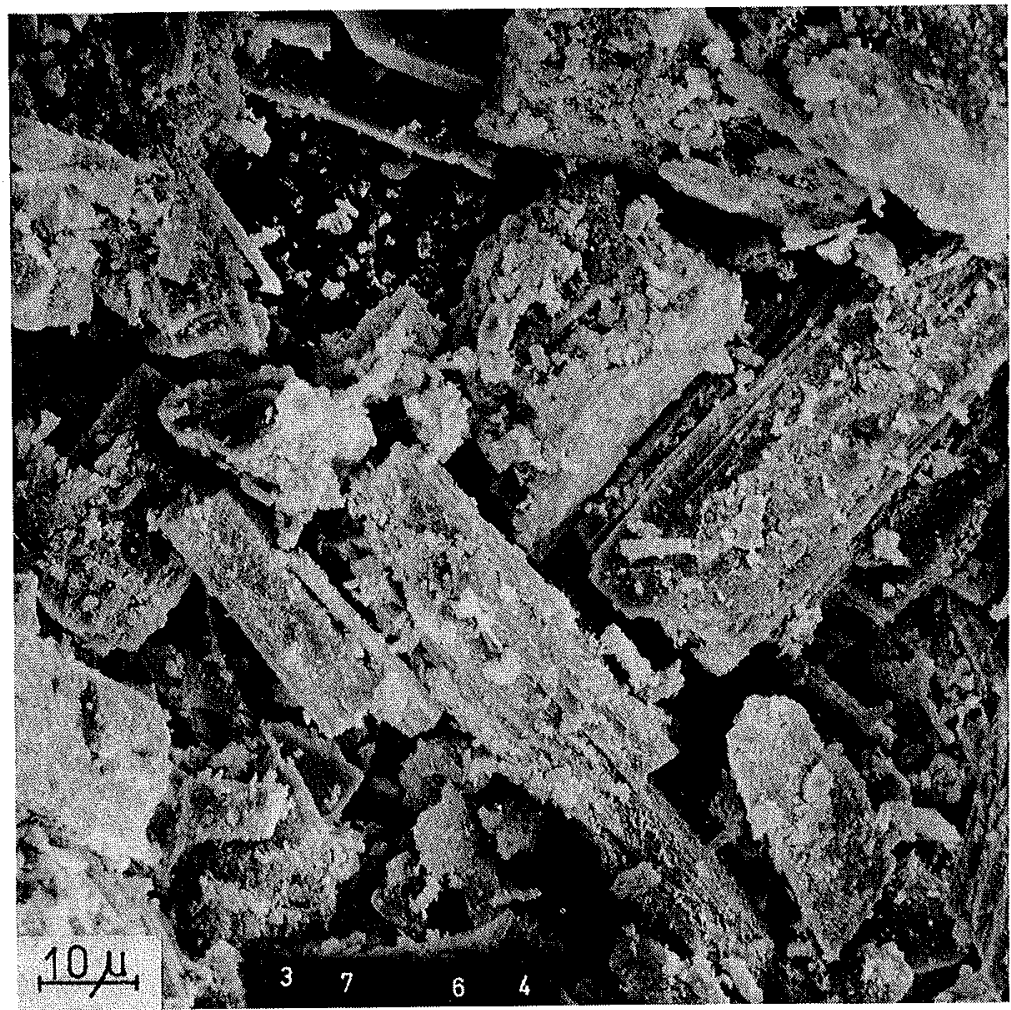

Figure 4 - Electron microphotograph of creaseyite

CONCLUSION X-ray powder diffraction data and chemical analysis identify the fine acicular green mineral found in the oxidation zone of the lead-copper deposit of the Cruz del Sur mine, Rio Negro Province, Argentina, as "creaseyite", first reported by Williams and Bideaux (1975). But there are some differences between the amounts of elements in the mineral from Arizona and Sonora, as reported by those authors and the Cruz del Sur specimen. The ideal composition of creaseyite indicated by Williams and Bideaux (1975) can not be applied to the. mineral of this study, and the writers propose the following ideal composition for it:

$$
\left(\mathrm{Pb}, \mathrm{Cu}, \mathrm{Fe}^{+2}, \mathrm{Zn}\right)_{4}\left(\mathrm{Al}, \mathrm{Fe}^{+3}\right)_{2} \mathrm{Si}_{5} \mathrm{O}_{17} \cdot 6 \mathrm{H}_{2} \mathrm{O} \text {. }
$$

Acknowledgements The writers wish to thank Dr. Sadao Tsutsumi of the Waseda University for his kindness in obtaining the infrared spectroscopic data, and staff members of the Consejo Nacional de Investigaciones Cientificas y Tecnicas for taking the scanning electron microphotograph of this mineral. 


\section{REFERENCES}

HAYASE, K., and DRISTAS, J.A. - 1972 -- Presencia de mottramita em la zona de oxidación del yacimiento de plomo, cobre y zinc, Mina Cruz del Sur, Los Menucos, prov. de Rio Negro, Rep. Argentina: Rev. Asoc. Geol. Arg. 27 : 300-308

STOUT, G.H., and JENSEN, L.H. - 1968 - X-ray structure determination, A practical guide: The Macmillan Co., London

WILLIAMS, S.A., and BIDEAUX, R.A. - 1975 - Creaseyite, $\mathrm{Cu}_{2} \mathrm{~Pb}_{2}(\mathrm{Fe}, \mathrm{Al})_{2} \mathrm{Si}_{5} \mathrm{O}_{17} \cdot 6 \mathrm{H}_{2} \mathrm{O}$, a new mineral from Arizona and Sonora: Min. Mag. $40: 227-231$ 